\title{
The Impact of Causal Ambiguity on Competitive Advantage and Rent Appropriation
}

\author{
Véronique Ambrosini \\ Birmingham Business School, University of Birmingham, Edgbaston, Birmingham \\ B15 2TT, UK \\ v.l.ambrosini@bham.ac.uk
}

Cliff Bowman

Cranfield School of Management, Cranfield, Bedford MK43 OAL, UK cliff.bowman@cranfield.ac.uk

We seek to develop the conceptual and practical understanding of causal ambiguity. Specifically we extend current thinking by setting out three types of causal ambiguity, based on whether firm resources are perceived to display linkage and/or characteristic ambiguity, and by examining for each type the impact of causal ambiguity on the sustainability of competitive advantage and on rent appropriation. We highlight the difficulties decision-makers face when they perceive ambiguity and finally we explore some implications of ambiguity with respect to resource-creation processes.

\section{Introduction}

The resource-based view (RBV) examines the link between the internal characteristics of a firm and firm performance (Barney, 1991; Barney and Arikan, 2001). It suggests that resources that are simultaneously valuable, rare, imperfectly imitable and imperfectly substitutable are a firm's main source of sustainable competitive advantage; these resources generate rents (Barney, 1991). However, as argued by Priem and Butler (2001) there is still a lack of understanding about exactly how rents are generated and appropriated. Rents persist partly because of the presence of isolating mechanisms that prevent other firms from replicating resources (Rumelt, 1984). Causal ambiguity is one of these mechanisms and it refers to situations where

We would like to thank Professor van Dick and two anonymous reviewers for their insightful comments. Thanks to their help we have been able to develop a clearer and more elaborated argument. 
the causal connections between actions and performance are unclear and hence the factors responsible for performance differentials are difficult to identify (Lippman and Rumelt, 1982). Causal ambiguity limits competitive imitation because competitors do not know the underlying reasons for a rival firm's effectiveness and so they cannot identify what they should be imitating (Rumelt, 1987).

It is also possible that managers inside a firm may not fully understand their own firm's sources of advantage (Barney, 1991). Szulanski (1996) argues that reducing internal 'stickiness' (which relates to the difficulty of transferring knowledge within a firm) can be key to a firm's ability to achieve sustainable competitive advantage, and that causal ambiguity is one of the main impediments to the transfer of best practice within an organization. Hence, while causal ambiguity is an isolating mechanism impairing the transfer of valuable activities across rival firms, it can also hinder the movement of valuable knowledge within the firm. Thus the effects of causal ambiguity on the sustainability of competitive advantage are mixed (McEvily, Das and McCabe, 2000).

There are a few studies specifically dedicated to the topic (Ambrosini and Bowman, 2005; Blyler and Coff, 2003; King, 2007; King and Zeithaml, 2001; Mosakowski, 1997; Powell, Lovallo and Caringal, 2006; Simonin, 1999; Szulanski, Cappetta and Jensen, 2004) (see Table 1 for these papers' key points). However, despite it being a core concept in the RBV causal ambiguity is still in need of clarification, and remains relatively under-explored (King, 2007; King and Zeithaml, 2001).

Our purpose here is to respond to King (2007)'s call for further research into the impact of causal ambiguity on firm resources and firm performance. We aim to extend our current understanding of causal ambiguity specifically by developing some insights into the effects of its presence on sustainable competitive advantage and on rent appropriation. Resource-based competitive advantages may generate rents, but these rents may be appropriated by other stakeholders, e.g. employees, through the exercise of their bargaining power (Bowman and Ambrosini, 2000; Coff, 1999; Peteraf, 1993). Hence competitive advantages may not lead to improved firm financial performance if rents are captured by other stakeholders. 
Table 1. Causal ambiguity: some key contributions

\begin{tabular}{|c|c|}
\hline Authors and date & Articles' key points \\
\hline Lippman and Rumelt (1982) & $\begin{array}{l}\text { The first to propose a definition of causal } \\
\text { ambiguity: 'ambiguity surrounding the } \\
\text { linkage between action and performance' ( } p \text {. } \\
421 \text { ) }\end{array}$ \\
\hline Reed and DeFillipi (1990) & $\begin{array}{l}\text { Explained that tacitness, complexity and } \\
\text { specificity were sources of causal ambiguity. } \\
\text { Suggested that 'reinvestment in causally } \\
\text { ambiguous competencies is necessary to } \\
\text { protect' a firm's resource-based competitive } \\
\text { advantage (p. } 88 \text { ) }\end{array}$ \\
\hline Mosakowski (1997) & $\begin{array}{l}\text { Explored how causal ambiguity could affect } \\
\text { decision making. Emphasized the need to } \\
\text { develop understanding of how managers in } \\
\text { firms actually experience causal ambiguity }\end{array}$ \\
\hline Simonin (1999) & $\begin{array}{l}\text { Concentrated on the transfer of causally } \\
\text { ambiguous knowledge in alliances. } \\
\text { Investigated the antecedents of causal } \\
\text { ambiguity }\end{array}$ \\
\hline King and Zeithaml (2001) & $\begin{array}{l}\text { Introduced a distinction between linkage } \\
\text { ambiguity and characteristic ambiguity }\end{array}$ \\
\hline Blyler and Coff (2003) & $\begin{array}{l}\text { Examined how social capital could be used } \\
\text { by individuals to appropriate rent even when } \\
\text { their contribution was causally ambiguous }\end{array}$ \\
\hline Szulanski, Cappetta and Jensen (2004) & $\begin{array}{l}\text { Studied the effect of causal ambiguity on } \\
\text { trustworthiness }\end{array}$ \\
\hline Ambrosini and Bowman (2005) & $\begin{array}{l}\text { Proposed a method to elicit causally } \\
\text { ambiguous resources within a firm }\end{array}$ \\
\hline Powell, Lovallo and Caringal (2006) & $\begin{array}{l}\text { Proposed that causal ambiguity is a } \\
\text { property of management perception }\end{array}$ \\
\hline King (2007) & $\begin{array}{l}\text { Developed a model of the sources of causal } \\
\text { ambiguity. Argued that future research into } \\
\text { causal ambiguity should investigate its } \\
\text { impact on firm resources and firm } \\
\text { performance }\end{array}$ \\
\hline
\end{tabular}


Building on Ambrosini and Bowman's (2005) and Powell, Lovallo and Caringal's (2006) papers that consider perceptions of causal ambiguity, we explore the moderating effects of causal ambiguity perceived by managers inside the firm on the sustainability of their firm's competitive advantage, and on rent appropriation (Powell, Lovallo and Caringal, 2006). For this purpose, in the next section we integrate Lippman and Rumelt's (1982), King and Zeithaml's (2001) and Powell, Lovallo and Caringal's (2006) work on causal ambiguity to enable us to define the concept precisely.

Following a review of definitions of causal ambiguity we identify three types of ambiguity perceived by managers within the firm. In the following section, for each type of ambiguity we explore the implications for competitive advantage and rent appropriation. Before concluding with a summarizing figure, having focused so far on causal ambiguity relating to the current resource stock, we discuss causal ambiguity and its impact on resource-creation processes.

We make several contributions in this paper. First we show that linkage and characteristic ambiguity can occur both separately and together. Second, while from the RBV one can deduce that causal ambiguity has a range of implications for the sustainability of competitive advantage, as a lack of causal ambiguity may increase the risk of competitive imitation, we develop these implications by suggesting that firms may lose their competitive advantage through the mismanagement of valuable resources. Third, we explore further the connections between causal ambiguity and value capture.

Our intention is not only to advance our conceptual knowledge, but also to explore some managerial implications. Managers need to perform a balancing act between enhancing the creation and leverage of valuable resources within the firm and simultaneously protecting the firm's resources from competitive imitation. They also need to understand how causal ambiguity can hinder or facilitate rent appropriation. We believe that, by achieving a fuller appreciation of causal ambiguity, managers should be able to make more informed decisions with respect to the resource base of their firm. 


\section{Defining linkage and characteristic ambiguity}

In 2001, King and Zeithaml set out two distinct dimensions of causal ambiguity: characteristic ambiguity and linkage ambiguity. They explain that linkage ambiguity is 'ambiguity among decision makers about the link between competency and competitive advantage' (2001, p. 77) and characteristic ambiguity is 'ambiguity inherent to the resource itself' (2001, p. 77). As we are interested in perceptions of causal ambiguity (Powell, Lovallo and Caringal, 2006) we interpret characteristic ambiguity as follows: because of the complex nature of the resource managers are not likely to fully understand how it 'works'. This complexity is likely to be due to the fact that many resources are in effect a combination of various interrelated and complementary tangible and intangible components (we address this more fully in the discussion). There are a range of factors that can cause linkage ambiguity. King and Zeithaml (2001), Reed and DeFillipi (1990) and Simonin (1999) propose that tacitness, complexity and characteristic ambiguity are such antecedents. Based on Lippman and Rumelt (1982) and Powell, Lovallo and Caringal (2006), we would add a separate group of 'managerial variables' that lead to linkage ambiguity. For instance, where the size and scope of the firm is extensive, individual managers may only be able to comprehend a limited sub-set of its operations. Similarly, newly recruited managers may only have a partial view, which could become more elaborated through experience. Linkage ambiguity may also occur where time pressures prevent managers from exploring the full scope of the firm's operations. Managers may display functional bias in perceptions (Walsh, 1988), maybe privileging their function's contribution to success over the contributions of other functions, and, more generally, managers experience bounded rationality (Simon, 1955). They engage in cognitive simplification, and their decision making and information processing are inevitably constrained by their past experiences. We could also add within this category of managerial variables ignorance of the existence of a resource, and erroneous beliefs about the impact of a resource formed through prior experiences, maybe in a different context or set of circumstances.

In summary, integrating Lippman and Rumelt's (1982), King and Zeithaml's (2001) and Powell, Lovallo and Caringal's (2006) work, we would argue that linkage ambiguity is about perceived ambiguity between resources and performance and it exists where a decision-maker perceives he/she has an incomplete understanding of 
the causes of his/her firm's success. In other words linkage ambiguity relates to managerial perceptions in relation to a specific resource or bundle of resources and it is ambiguity about the link between resources and performance. This perceived incomplete understanding can be caused by characteristic ambiguity, i.e. the complex nature of the resource itself, or it could result from managerial variables, like limited tenure, functional bias etc. In short characteristic ambiguity concerns the obscurity of the inner workings of the resources. This means that characteristic ambiguity and linkage ambiguity should be considered as separate constructs.

\section{Combinations of linkage and characteristic ambiguity}

In what follows, building on our argument so far, we propose four combinations of causal ambiguity (see Figure 1 ). The resource, from a manager's perspective, either does or does not display linkage ambiguity and either does or does not display characteristic ambiguity. This generates three combinations of causal ambiguity (types $1,2,3$ ) and one representing the absence of causal ambiguity (type 4).

For each of these combinations we address issues of rent appropriation and the sustainability of competitive advantage. As we have argued, linkage ambiguity can be the result of characteristic ambiguity, and/or it can result from a variety of other variables that impact an individual manager's understanding of the firm's value creation processes. In what follows we explore the three combinations of causal ambiguity with regard to how rents accrue in firms, how they may persist, and how and why particular organizational members might be able to appropriate these rents. 


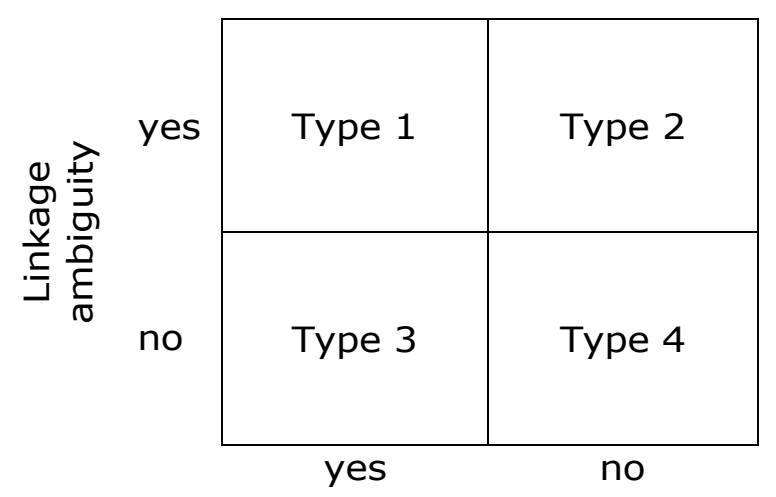

Characteristic ambiguity

Figure 1. Combinations of linkage and characteristic ambiguity

Following the RBV argument we know that sustainable competitive advantage derives from valuable $(\mathrm{V})$, rare $(\mathrm{R})$, difficult to imitate (I) and non-substitutable (N) resources (Barney, 1991, 2001). ${ }^{1}$ These resources can be anything within the firm, i.e. exclusive contracts, relationships with suppliers, retailing facilities, organizational processes, efficient factories, patents, brands, tacit know-how etc. (Barney, 1991), and they have either been artfully procured (Makadok, 2001) or they have been built or created within the firm (Helfat et al., 2007). To generate rents, resources must be involved in the creation of valuable products or services. In this paper we focus on value creating activities performed by individuals and groups within the boundary of the firm that fulfil Barney's VRIN criteria (Johnson, Melin and Whittington, 2003;

${ }^{1}$ In 2002 Barney formulated the original VRIN criteria differently and proposed the VIRO (or VRIO) criteria. The $\mathrm{V}$ and $\mathrm{R}$ are still the same - they relate to value and rarity. The I relates to imitability (and substitutability as in effect a resource that can be substituted for is in essence the same as a resource that can be imitated). The $O$ is about organization, specifically whether a firm has other policies and procedures supporting the exploitation of VRIN resources (Barney and Hesterly, 2006). In other words a VRIN resource can be a source of sustainable competitive advantage but to be able to exploit the VRIN resource fully a firm must be organized to do so. 
Orlikowski, 2002; Penrose, 1959; Porter, 1996; Whittington, 1996). ${ }^{2}$ Valuable activities involve both people and the resources that surround them; using the broad sense of the word resource, activities are a combination or configuration of resources. Quite how this configuration 'works' to deliver advantage may not be well understood by some managers, i.e. it may be characteristically ambiguous. This may happen even if the individual components that combine into the configuration are readily comprehended; what is not clear are the inner workings, the synergistic interactions between the components of the system that collectively deliver advantage.

We assume a stream of rents flowing to the firm, these rents being generated by valuable activities and the resource configuration. We focus on the effects of managerial perceptions of causal ambiguity on competitive advantage and its sustainability and we also examine how causal ambiguity may affect the capture of rents within the firm. For the purposes of this exploration we assume that managers act in the interests of the firm's shareholders. Following Coff (1999) we suggest that the perceived presence or absence of causal ambiguity affects the perceived bargaining power of people within the firm, and we assume that rents not appropriated by employees are available for subsequent dispersal to other stakeholders (shareholders, other suppliers etc).

We now explore each of our combinations of causal ambiguity to understand what they mean in terms of the management of valuable activities, the sustainability of competitive advantage and rent appropriation.

\section{Type 1: Managers perceive both linkage and characteristic ambiguity}

The impact on competitive advantage

Here managers are not only unclear whether the activity is valuable, but they are also unable to fully comprehend how it is performed. One obvious danger here

\footnotetext{
${ }^{2}$ We recognize that not all people or all human actions are a source of competitive advantage; generic activities are a source of competitive parity, unproductive activities destroy value. We also acknowledge that VRIN resources can be anything within the firm and hence some tangible resources may be critical and be sources of superior performance.
} 
is that the activity may be vulnerable to inappropriate changes. An activity whose link with competitive advantage is not understood could be outsourced, altered to be 'improved', or even eliminated altogether to cut costs. Such an activity could be changed through the actions of new management entering the firm where they lack insights into the idiosyncrasies of the firm and its customers. If a recently recruited executive is expected to implement rapid and significant change causally ambiguous activities may be the first to be eliminated, because they are not seen to matter.

If causal ambiguity is due to characteristic ambiguity and particularly tacitness or path dependency in the development of a firm-specific bundle of activities (Kor and Mahoney, 2004), then these valuable activities, if left alone, are likely to be a source of sustainable competitive advantage (Barney, 1991; Reed and DeFillipi, 1990). If both managers and competitors do not fully comprehend the causes of the firm's competitive advantage, because it is created by tacit, difficult to express and codify activities, then this advantage is likely to be sustained because managed imitation cannot take place. There is still, however, the possibility that the effect or impact of these activities may be achieved by other firms through other means, i.e. substitution (McEvily, Das and McCabe, 2000). The problem when managers perceive both types of ambiguity is that, because of the tacit and complex nature of such activity, when lost, because it is not stored in any knowledge management systems, it may be difficult to reinstate even if, with later insight, its value is recognized.

Hence an activity that is both linkage and characteristically ambiguous is likely to be a source of sustainable advantage. However, the lack of perceived understanding of its significance puts it at risk; the competitive advantage may only be sustained by luck. Johnson, Scholes and Whittington (2005) explain the case of Plasco, a manufacturer of plastic goods which was outperforming its competitors. Up to a strategic intervention aimed at surfacing causes of success, nobody in the company had realized that employees were systematically breaking the rules, the standard procedures set out by management, in order to please powerful customers. This meant that it was easier to respond to customer demand. If managers tried to ensure that the 'proper' procedures were followed they could well have lost their advantage, as they would have probably become less flexible. 
Where type 1 ambiguity occurs it is possible that those performing these valuable but under-appreciated activities may autonomously choose to change their behaviours. If what they do is not seen to be special or valuable by their managers they may decide to alter their performance in some way. We can refer to Feldman and Pentland's (2003) distinction between 'ostensive routines', the structure or abstract understanding of the routine, and 'performative routines', the actual performance of the routine, the routine in practice. It may be that the ostensive activity continues to be performed as before; however, it might be that variations in the actual performance of the valuable activity take place. Subtle and detailed differences between competing firms are often strategically important (Whittington, 1996), and hence any variations may be detrimental to the firm, and managers may not realize because of the presence of causal ambiguity that these variations have occurred.

\section{The impact on rent capture}

In the type 1 situation managers do not fully comprehend the link between the activity and firm performance, nor do they understand the activity itself. The activity may involve subtle tacit routines or complex interrelationships between the staff involved in the activity (Reed and DeFillipi, 1990). Those involved in the valuable activity may not know the 'true' value of their work, its ultimate impact on firm performance. In these circumstances, because the contribution of the activity is obscure, the rents it creates are more likely to remain within the firm, and hence help to boost profits (Coff, 1999). Where those performers of these valuable activities are not cognizant of the firm's dependence on their efforts, there will be no behavioural uncertainty (Kulkarni and Ramamoorthy, 2005) and hence employees are unlikely to try to 'hold up' the firm, i.e. to try to appropriate these rents (Williamson, 1985). They are unlikely to seek to capture the rents they help to create in the form of higher salaries (Kotowitz, 1989; Williamson, 1975).

However, Blyler and Coff (2003) argue that more people can make a demand on the rents generated when managers perceive linkage causal ambiguity as there is no available proof that their demands are well grounded or not. They suggest that because of this linkage ambiguity people can take credit for success as the causality is unclear, and hence the 'claims on the rent may seem legitimate since they would be hard to disprove' (Blyler and Coff, 2003, p. 682). Some claims may be perceived 
to be legitimate, but some not and may not be perceived by others to be fair, but people with strong social capital and power may have few problems in making and sustaining these claims. This suggests that perceiving characteristic and linkage ambiguity is a source of transactions costs. It may also make it costly and difficult to write contracts and enforce performance norms in these ambiguous circumstances. Causal ambiguity may therefore reduce the rent appropriated as a whole by the firm (Foss and Foss, 2005). This suggests that causal ambiguity creates another tradeoff between protecting against the amount of rent captured by organizational members and the loss of rent due to transaction costs from protection measures set up to avoid this rent capture (Foss and Foss, 2005). However, a counter argument would be that if managers acting in the interests of the firm owners do not perceive activities to be special in any way, as here in the type 1 case, we could surmise that they may be unlikely to give in to any attempts to 'hold up' the firm.

Both arguments, while at first sight opposing, can be reduced to one suggestion: when characteristic and linkage ambiguity is perceived the rent captured by those performing the causally ambiguous valuable activity will be determined by the bargaining power they are perceived to have and that they choose to exercise. It can also reflect the difference in assumptions between the RBV and transaction cost theory. The latter 'emphasizes the downside associated with [...] uncertainty in describing how [it . ..] may lead to misappropriation or hold-up problems' (Williamson, 1985). In contrast, '[the RBV . . .] emphasizes the upside profit creating opportunities associated with uncertainty' (Leiblein, 2003, p. 952). In other words, causal ambiguity is a negative factor when we follow the transaction cost argument as it creates measurement and monitoring problems and hence increases transaction costs (Madhok, 2002), and for the RBV it may have both positive and negative aspects. However, as noted by Kulkarni and Ramamoorthy (2005) it is appropriate to view both theories as complementary, as in order to achieve the best possible profits firms should consider both transaction cost minimization and creating value from idiosyncratic activities. 


\section{Type 2: Managers perceive linkage ambiguity but no characteristic ambiguity}

The impact on competitive advantage

In this case the activity is understood, but managers do not perceive the link between the activity and competitive advantage; they are not aware of its 'true' value. There are many examples of firms where managers did not understand the value of activities, although they were fully cognizant of the nature of the activities. The examples include failures that some firms have suffered from downsizing, notably in the 1990s when many business process reengineering projects took place. Kilpatrick (1999) narrates in detail what happened in an American hospital when the management decided to reduce the workforce after a \$16 million budget shortfall. She explains how those in charge were not knowledgeable about the value of the activities of the department whose workforce was to be cut and how some of the employees who were dismissed were critical to the day-to-day operation of the hospital. Here the activities were understood by managers but their significance was not appreciated.

Managers may be unaware of the value significance of some activities due to factors other than characteristic ambiguity, such as the size of the organization and the complexity of its processes (Lippman and Rumelt, 1982). They may feel driven to improve performance, but may lack insight into the true value generating activities of the firm. This may, for instance, lead them to focus primarily on generic cost reduction strategies, which may be unable to differentiate between high and low value activities, risking the elimination of the good along with the bad.

The managerial climate and predominant leadership style in some firms may also further exacerbate these problems. Where there are limited communications, poor relationships across organizational levels, particularly in a 'barren' organizational context (Szulanski, 1996) or where agency tensions are heightened (Lee and O'Neill, 2003), people engaged in valuable activities may not normally or comfortably engage in dialogue with managers. In a climate of cost reduction there may be even less incentive to do so. Where managers make changes in these circumstances, changes that organizational members know will be detrimental to for example service delivery, a culture of cynicism, resignation and disillusionment may be promoted. Drastic downsizing and cost cutting may be performed by managers 
new to the business, who have been drafted in especially to effect these unpopular measures. By coming in from outside, they are less likely to have their actions affected by emotional commitments to past practices, individuals or groups, but the downside is they may cut out activities that contribute to advantage (Black and Boal, 1994). Alternatively, advantage is likely to be sustained if managers seek to develop a culture that encourages interaction and the sharing of knowledge between organizational members, and hence reduces linkage ambiguity.

Losing advantage through managerial action is not the only danger facing a firm. It may also lose its advantage through competitive imitation. An activity that is not characteristically ambiguous could be codified and people moving to another firm might be in a position to explain what they used to do. Their new employers may be able to recognize the value of the activity and ask the newcomers to introduce these activities, i.e. for their new employers these practices are neither characteristically nor linkage ambiguous.

\section{The impact on rent capture}

Where activities do not display any ambiguity one might expect an informed negotiation with regard to rent appropriation. However, where managers perceive linkage ambiguity but not characteristic ambiguity the situation is probably more complex. As explained earlier, the managers' linkage ambiguity may be due to poor organizational climate and the lack of communication between those involved in the activity and managers, but here in this case there is no characteristic ambiguity. We could surmise that in this situation organizations may be exposed to moral hazard as those involved in a valuable activity have an incentive to make this well understood by managers and may demand additional reward for their contribution to the firm's success (Coff, 1999; Hennart, 1993), but those performers of the valuable activities may be in a stronger position to capture their portion of the rents they generate if they can be rewarded without having to 'show their cards'. Here we are faced with the familiar agency problem of organizational members pursuing their own interests (Eisenhardt, 1989; Jensen and Meckling, 1976; Roberts, McNulty and Stiles, 2005).

However, practically it is likely that it may be difficult for them not to inform the managers about the value of the activities in order to bargain up their share of the value they help create, and hence such a situation is likely to be short lived. 
Managers are unlikely to concede to demands where they do not perceive the activities in question to be particularly special or valuable to the firm. Moreover we can also invoke the argument of context specificity and interdependence. If the activity is firm specific or there are strong interdependences between the activity and other assets, those involved in the valuable activity may not be able to convincingly argue that their skills can be readily transferred to a rival firm, because managers may realize that the activity may not be worth as much to another firm (Dierickx and Cool, 1989; Thomke and Kuemmerle, 2002). This situation is likely to be found in complex organizations and notably in transnational corporations where there are extensive interconnections across the structure, where the modus operandi is collaboration and integration with a strong reliance on relationships both inside and outside the corporation (Eisenhardt and Martin, 2000; Ghoshal and Bartlett, 1998).

\section{Type 3: Managers do not perceive linkage ambiguity but perceive characteristic ambiguity}

The impact on competitive advantage

In this situation managers are aware that some activities are sources of advantage but they do not fully comprehend how the activity is performed. Activities may be so complex that the workings of the valuable activities remain obscure or they are not fully comprehended because they have tacit elements (Castanias and Helfat, 1991).

An example of an activity displaying characteristic ambiguity but no linkage ambiguity could be that described at Credit Suisse First Boston (see Blyler and Coff, 2003). Frank Quattrone and his 100 member team were central to Morgan Grenfell's success, a fact that was well known in the industry. Executives at Credit Suisse realized they were not able to replicate Morgan Grenfell's sources of success so they acquired Quattrone and the whole team. A similar conclusion was reached by Groysberg and Abrahams (2006) who explained that organizations were recruiting high-functioning teams who had been working together effectively, rather than trying to recruit specific individuals. Similarly Groysberg and Lee (2008) concluded that Wall Street analysts are very dependent on the quality of their colleagues and that before considering moves they should take this into consideration as they may find that they may not be able to perform as well in a 
different organizational context. This suggests an absence of linkage causal ambiguity, but the presence of characteristic ambiguity.

An interesting question is whether firms should strive to reduce characteristic ambiguity or actively seek to encourage it. We could take the example of Formula 1 teams to examine this.

'Some Formula 1 teams are so concerned about secrecy and the loss of intellectual property that they literally build physical walls around departments to ensure that if someone leaves from the transmission department, they won't have an idea of what's going on in the suspension department... . In contrast we have the view that providing we are progressing and developing it is more positive to have an open internal exchange of information than the risk of losing intellectual property when somebody goes' (Patrick Head at Williams F1 quoted in Jenkins, Pasternak and West, 2005 , p. 145). In the $\mathrm{F} 1$ teams referred to at the start of the quote, characteristic ambiguity is deliberately fostered. Those involved in the VRIN activity may be unclear about how their work impacts on the ultimate performance of the car. Although they would be aware of the importance of improvements in transmission systems, they are not aware of the interaction effects between their efforts and the efforts of other sub-teams and one could probably assume that nobody has a perfect overall understanding. Maybe by keeping the sub-teams physically separated the $\mathrm{F} 1$ team reduces the threat of imitation by a rival team should an individual leave.

The Williams F1 team, on the other hand, is keen to facilitate knowledge transfer in order to innovate and hence the managers strive to reduce characteristic ambiguity. These instances can also be seen as an illustration of the difference between architectural knowledge and component knowledge. Architectural knowledge requires an understanding of the differing elements of a system, but is particularly concerned with the way the different components are linked and integrated to form a coherent whole, whereas component knowledge relates to each of those specific elements (Clark, 1985; Henderson and Clark, 1990). Hence another way of interpreting these $\mathrm{F} 1$ firms is that managers may not perceive linkage ambiguity where they have architectural knowledge. However, if, as is likely, they do not fully understand how each distinct activity contributes to the 'bigger picture', they experience characteristic ambiguity. 
These examples also illustrate a paradox of causal ambiguity. If managers encourage a shared understanding of how the firm gains advantage by trying to reduce characteristic ambiguity, the firm increases the risks of competitive imitation. As explained by Zander and Kogut (1995), resources based on knowledge that can be codified and then communicated are most likely to be replicated and then imitated. However, if managers act to restrict codification or the passing on of knowledge the firm may lose opportunities for innovation (Winter, 1995). Characteristic ambiguity may make it difficult for a firm to transfer valuable activities to other parts of the organization, but it also makes it difficult for competitors to imitate these uncodified activities. Nevertheless where managers are aware of the value of an activity, even though it may be characteristically ambiguous to them, they should be able to take the necessary steps to protect it, thereby prolonging competitive advantage.

This aspect of causal ambiguity represents a 'mixed blessing' for both strategic management scholars (Lado et al., 2006, p. 121) and resource owners. A key question is whether replication within the firm and imitation by competitors are inextricably linked (Kogut and Zander, 1992; Rivkin, 2001; Winter, 1995; Zander and Kogut, 1995). The answer perhaps unsurprisingly is that it depends on a range of phenomena and notably the complexity, observability or tacitness of the resource (see Winter, 1995, p. 170, for a full list); in other words it depends on how characteristically ambiguous the resource is. While resources that are not characteristically ambiguous are most likely to be replicated and imitated (Zander and Kogut, 1995), Rivkin (2001) argues that on the other hand highly characteristic ambiguous resources are most unlikely to be replicated internally or imitated by rivals. Rivkin (2001, p. 275) proposes that "'moderate" levels of complexity can make imitation more difficult than replication'. When the resource is too complicated any efforts to replicate are likely to be critically affected by any small errors in the replicated resource. When the resource is moderately complex then the original firm can use its past experience (its original 'template') to replicate the resource, but the resource is complicated enough to make imitation difficult for competitors. This is the case because the replicator, as explained by Rivkin (2001), has an informational edge: the original firm has an understanding of the original resource-creation process. 
If the activity is characteristically ambiguous because it is tacit or complex and involves interactions within a web of people, no single individual involved may be aware of the true value of their efforts, or how they each contribute to overall performance (in other words the activity is linkage ambiguous to its performers), and as a consequence the motivations to seek to bargain up their share of the value created will be low. The rent stream generated by this activity is thus more likely to be retained by the firm, rather than captured by the performers of the valuable activity. In this sense we can surmise that it would probably be in the interests of the managers (acting in the interests of shareholders) to prolong this situation. However, whilst in terms of value capture this may seem positive to the firm, it may not be a very motivating situation for people who may want to know how they directly contribute to performance. They may cease performing in the same way. This may at first sight be an unlikely problem for a firm. However, in many mature markets advantage may be gained and sustained through quite subtle and seemingly trivial differences between products/services and the ways they are marketed and delivered. If the value of these small but important differences is not understood across those involved in the valuable activity, they may eliminate them, and they may not think it necessary to ensure that new recruits perform them.

While characteristic ambiguity can be positive for value capture it may be negative in terms of organizational learning and hence negative for the long-term future of the firm, so it might actually be beneficial to reduce ambiguity. So, in order to maintain, develop and transfer these valuable activities people need to share their experience, to have exchanges with other organizational members, as socialization, interaction and cooperation are all key enablers for the sustainability and development of characteristically ambiguous practices (Orlikowski, 2002). Thus managers may wish to adopt learning strategies and foster collaboration (Teece, Pisano and Shuen, 1997). This could be all the more critical if the activity is firm specific and tacit. Indeed if the activity is tacit and critical to value creation, managers should endeavour to protect it knowing that because of its embedded, idiosyncratic and complex nature the people involved in the activity cannot be easily replaced. Hence if managers want to explore and exploit these valuable activities, they may want to attempt the fostering of conditions 
that circumvent ambiguity and promote knowledge transfer, such as collective discussions, debriefing sessions and performance evaluation processes. By sharing their experiences organizational members can achieve an improved level of understanding of the 'causal mechanisms intervening between the actions required to execute a certain task and the performance outcomes produced' (Zollo and Winter, 2002, p. 342).

The challenge to managers is again to promote the spreading of valuable practices in ways that do not increase the likelihood of competitor replication, and to do so without provoking those involved in the valuable activity to bargain up their share of the rents they create by drawing attention to their idiosyncratic and valuable activities. In many respects it could be in this situation where firms may benefit from developing a stewardship approach to ensure that the goals of everybody are in some sense aligned (Davis, Schoorman and Donaldson, 1997). They may be able to do so by developing high levels of organizational identification (Mael and Ashford, 1992), or by ensuring that the firm has motivating rent sharing strategies (Coff, 1997). In short managers may want to ensure that they promote proorganizational behaviour such as a collectivist culture, low power distances and an involvement-oriented situation (Tosi et al., 2003), i.e. a work context in which, according to stewardship theory, individuals will act in the firm's interest (Tosi et al., 2003). 


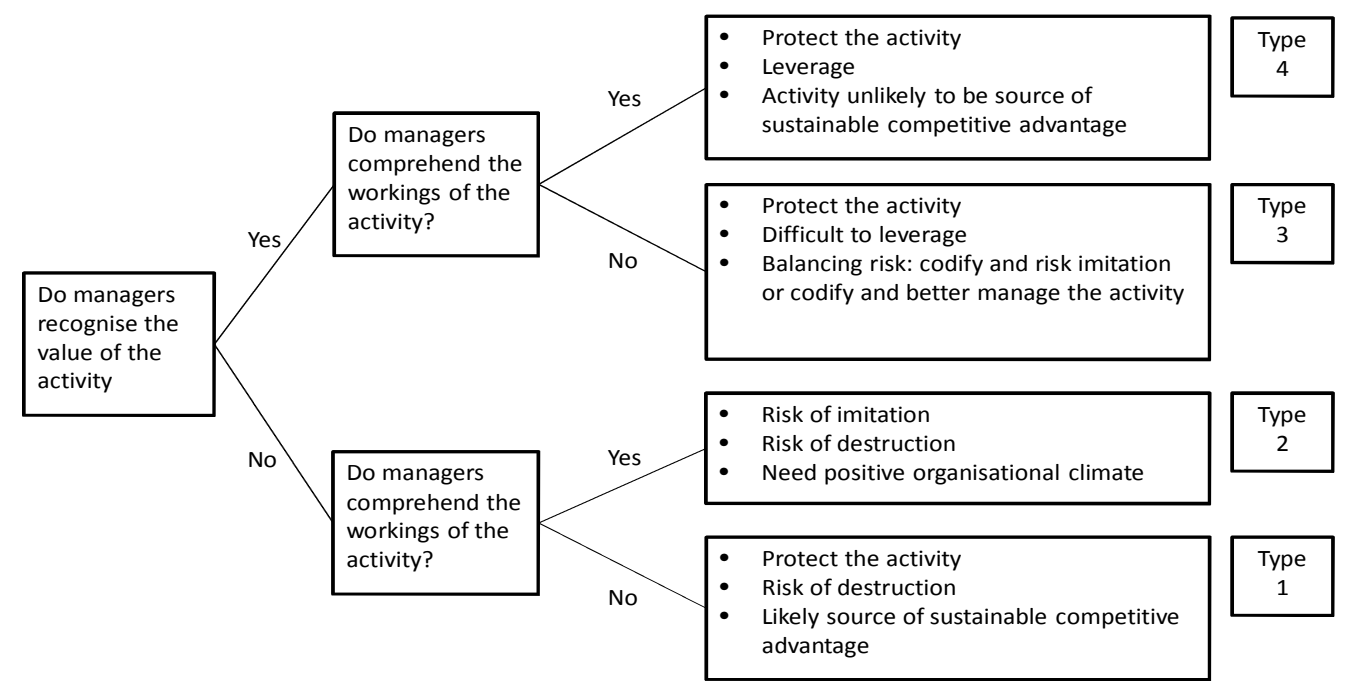

Figure 2. Key managerial issues emanating from causal ambiguity

\section{Type 4: Managers perceive neither linkage nor characteristic ambiguity}

Type 4 refers to an absence of causal ambiguity. We could assume that type 4 conditions represent the bulk of organizational activity that is addressed in normal managerial behaviour and discourse, particularly where managerial prescriptions are being discussed. If there is no ambiguity stemming from these activities it means that it is likely that they are understood and can be actively and appropriately managed. If the valuable aspect of the activity is particularly well understood it can also potentially be made more efficient or even more effective, so as to further enhance its value. However, if there is no causal ambiguity or other isolating mechanisms, i.e. 'any knowledge, physical, or legal barriers that may prevent replication' (Lepak, Smith and Taylor, 2007, p. 188) such as firm-social network specificity or specialized knowledge, there is a risk that the valuable activity may readily be spread to other firms (Badaracco, 1991; Barney, 1991). Noncausally ambiguous activities are unlikely to be unique for long. Once other rival firms have managed to imitate these activities they may become a source of competitive parity (Barney, 1995). 
The descriptions of the various combinations represent likely scenarios that managers may face. They are summarized in Figure 2. Of course our explanations are simplified abstractions from reality and they do not fully reflect the complexity of organizations. This, however, shows some of the difficulties managers have to deal with in trying to manage sources of advantage. We could suggest that causal ambiguity is less likely to be present and problematic in organizations where learning from experience, learning by doing and knowledge transfer in general is favoured (Simonin, 1999), and where organization structures and systems are flexible and fluid (Grant, 1996). It can also be suggested that managers may be better off having a stewardship perspective on corporate governance that emphasizes collaboration rather than a pure agency approach (Coff, 1999; Sundaramurthy and Lewis, 2003).

\section{Discussion}

We have focused on activities; however, as noted earlier the RBV takes a wider perspective which encompasses anything within the firm that can be identified as rent generating. Generally though, while some tangible inputs may be rare and inimitable and, if valuable, a source of advantage, resources that are non-human, e.g. machinery, products, systems, are likely to be more susceptible to being imitated over time (Hunt and Morgan, 1995). Also, in practice resources rarely operate in isolation as value creation involves interactions and synergistic effects between bundles of resources. It may be difficult to identify how a specific resource contributes to competitive advantage as advantage is based on a complex pattern of interlinked physical, informational, relational etc. factors and a single specific resource is unlikely to be isolatable as the sole source of firm advantage. The value of a resource is often contingent upon the presence of other resources (Dierickx and Cool, 1989; Lippman and Rumelt, 2003). In other words our discussion of causal ambiguity and notably the impact on competitive advantage could be extended to the entire set of a firm's resources.

Morgan and Hunt (1999) explain that when dealing with resources managers have to be aware that there are four main requirements. (1) managers must acquire or develop resources; (2) they must combine resources so that they develop a unique and valuable combination of resources; (3) they must ensure that resources are used in the right markets as resources that are valuable in one competitive context may 
not be as effective in another (Castanias and Helfat, 1991); and (4) they must maintain and protect the resources as they are used, in other words 'organizations must continuously reinvest in the resources that it anticipates will best serve its strategy' (Morgan and Hunt, 1999, p. 283). Clearly these four tasks become much more challenging in the presence of ambiguity.

Managers are aware that standing still is most probably not an option when the firm depends totally or partially on resources that may be subject to imitation or produce diminishing returns (Pachedo-de-Almeida and Zemsky, 2007) or that could become irrelevant because of changes in the environment (Teece, Pisano and Shuen, 1997).

For instance cost reducing processes or quality control systems may have been fully exploited and hence other resources need to be developed. Also some resources yield less and less as they are used, irrespective of competitor imitation. These issues of diminishing returns and sustainability of advantage deriving from resources are closely related to the types of resources the firm relies upon. For instance physical resources such as machinery or location are most likely to be subject to diminishing returns; hence the advantage deriving directly from them will not be sustainable. On the other hand relational resources such as trust or informational resources such as organizational learning (Hunt and Morgan, 1995) are likely to be enduring sources of advantage as they are difficult to imitate and their value does not diminish with use. Indeed some resources display increasing returns with use and may even have simultaneous uses (Collis and Montgomery, 1995).

These issues compounded with the fact that resources can be inadvertently destroyed highlight the importance of causal ambiguity for managers. Without being clear what causes advantage or understanding the inner working of their set of resources managers are unlikely to be able to reliably assess how to either maintain the value of their resources or enhance their resource base, or determine whether these resources need to be altered in view of exogenous changes or because the resources have been degraded through use.

Thus far we have focused on the problems and issues associated with managerial perceptions of ambiguity in relation to the extant stock of valuable activities. Next before concluding we turn our attention to causal ambiguity and the resourcecreation process. 
Resources can be created or acquired (Barney, 1986; Makadok, 2001) in various ways. New resources can be the outcome of luck, accident, ad hoc interventions or dynamic capabilities. Dynamic capabilities are the processes through which a firm's resource base is modified. They are 'the capacity of an organization to purposefully create, extend or modify its resource base' (Helfat et al., 2007, p. 1; emphasis added). Managers deploy dynamic capabilities to sustain or enhance performance; in other words they do not perceive any linkage ambiguity. They employ these processes deliberately because they believe they would impact on performance. However, these dynamic capabilities, for instance new product development activities or learning (Eisenhardt and Martin, 2000; Teece, Pisano and Shuen, 1997) may well be characteristically ambiguous to managers, i.e. they display type 3 ambiguity.

The definition of dynamic capabilities emphasizes the deliberate aspect of the resource-creation processes (Adner and Helfat, 2003; Helfat et al., 2007); however, these processes often have a strong emergent quality (Mintzberg and Waters, 1985). Resources that are socially complex and that have been built up over time (Barney, 1995) may not have resulted from deliberately managed processes. These resource-creation processes may display both characteristic and linkage ambiguity (type 1). Take for instance the example of Delta, a software company (Ambrosini and Bowman, 2005). It had essentially one product which had been developed a decade earlier. Since that time the firm had exploited this product, and they had incrementally developed it. The current challenge facing the executives was that they were unsure how the original product was created, and were unclear about whether and how they might be able to recreate the conditions to enable new products to be developed. Thus the past resource-creation process is causally ambiguous, which poses a serious challenge to the management who recognize that they need to innovate in order to sustain advantage. Because of ambiguity managers may have to 'reinvent the wheel' and hence lose valuable time and money in finding ways of renewing their resource base. Of course, resource-creation processes may not be causally ambiguous to those involved in them. However, over time as individuals leave the firm and are replaced by others who have had no experience of these processes knowledge about what was done and how it was done may no longer be accessible. Here we could not label this as a problem of ambiguity, but one of non-involvement leading to ignorance. 
Thus causal ambiguity is not only an issue for the management of a firm's current stock of valuable resources but also an issue for the future development of the resource stock. The discussion also shows that one cannot equate resource creation with dynamic capabilities alone. They are only part of the process; emergent, non-deliberate processes or luck also matter.

\section{Conclusion}

In this paper we have contributed to our understanding of causal ambiguity by first explaining that linkage and characteristic ambiguity could both occur independently or in tandem. We have also advanced current knowledge on the implications for the sustainability of competitive advantage by suggesting that advantage could be inadvertently eradicated by managerial actions, and lastly we have explored the impact of causal ambiguity on value appropriation in the firm.

In Figure 3 we summarize the main conclusions from our exploration of causal ambiguity. Reading from the left of the figure, we identify three antecedents of internal causal ambiguity: resource-creation processes, managerial variables and the resources themselves. We have explained how resource-creation processes can generate ambiguity, and resources that are complex can create characteristic ambiguity. We have also identified a variety of managerial variables, e.g. limited tenure in the firm, as precursors of ambiguity. The arrow from internal causal ambiguity back to the resource stock represents the possibility that ambiguity can lead to managers inadvertently destroying some subtle sources of advantage.

From the RBV literature we know that resources generate rents and they can also create external ambiguity reducing the likelihood of competitor imitation, thus leading to the sustaining of the rent stream. Along the top of Figure 3 we have represented the effect of managerial ambiguity on employee bargaining power. Where employees have strong bargaining power they may be able to appropriate a higher proportion of the rents. Thus bargaining power moderates the volume of profits captured by the firm. 


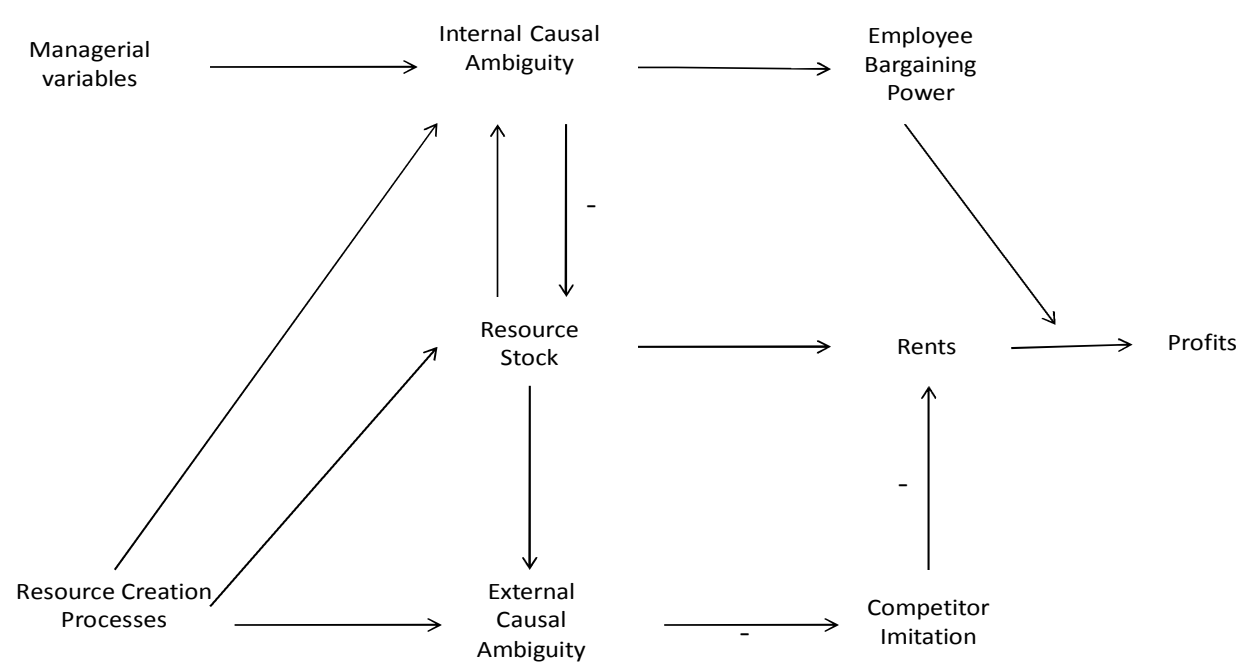

Figure 3. Causal ambiguity and rent capture

We have argued that linkage ambiguity is about ambiguity between resources and performance within the firm and it exists where a decision-maker perceives he/she has an incomplete understanding of the causes of his/her firm's success, due to variables such as firm size or bounded rationality or to characteristic ambiguity. Second, we have also proposed that causal ambiguity is multi-faceted and could essentially take three forms. By proposing these combinations of causal ambiguity we have addressed the issue of rent appropriation as well as rent generation in the presence of causal ambiguity (which as argued by Alvarez and Barney (2004) has not been featured in many RBV contributions). We have also demonstrated the relevance of causal ambiguity to management practice and in so doing we have made some progress towards making the RBV operationally valid (Priem and Butler, 2001). We have argued that managers face differing challenges depending on the combinations of causal ambiguity they experience. We have raised issues concerning the likely role of managers in relation to rent generating activities, and have suggested some implications for the longevity of rent streams likely to accrue to activity types categorized by the causal ambiguity they display. We have also suggested that causal ambiguity is a concept not only relevant to a firm's current resource stock but also to the resource-creation process. We could suggest that our 
arguments are akin to those of Penrose (1959) and Lockett and Thompson (2004) suggesting that managers are a firm's ultimate constraint.

As a final note we would like to suggest some avenues for future research. We suggest that the three combinations of causal ambiguity could be researched empirically to find evidence of their existence and to understand better the circumstances in which they occur, e.g. are there differences between industries, task stability etc. It might also be helpful to study how different managers may deal with causal ambiguity and how causal ambiguity impacts on 'what managers do' (Hales, 1999).

\section{References}

Adner, R. and C. Helfat (2003). 'Corporate effects and dynamic managerial capabilities', Strategic Management Journal, 24, pp. 1011-1025.

Alvarez, S. A. and J. B. Barney (2004). 'Organizing rent generation and appropriation: toward a theory of the entrepreneurial firm', Journal of Business Venturing, 19, pp. 621-635.

Ambrosini, V. and C. Bowman (2005). 'Reducing causal ambiguity to facilitate strategic learning', Management Learning, 36, pp. 517-536.

Badaracco, J. L. (1991). The Knowledge Link. Boston, MA: Harvard Business School Press.

Barney, J. B. (1986). 'Strategic factor markets: expectations, luck and business strategy', Management Science, 32, pp. 1231-1241.

Barney, J. B. (1991). 'Firm resources and sustained competitive advantage', Journal of Management, 17, pp. 99-120.

Barney, J. B. (1995). 'Looking inside for competitive advantage', Academy of Management Executive, 9, pp. 49-61.

Barney, J. B. (2001). 'Is the resource-based "view" a useful perspective for strategic management research? Yes', Academy of Management Review, 26, pp. 41-56.

Barney, J. B. (2002). Gaining and Sustaining Competitive Advantage. Upper Saddle 
River, NJ: Prentice Hall.

Barney, J. B. and A. M. Arikan (2001). 'The resource-based view: origins and implications'. In M. A. Hitt, R. E. Freeman and J. S. Harrison (eds), Handbook of Strategic Management, pp. 124-188. Oxford: Blackwell.

Barney, J. B. and W. S. Hesterly (2006). Strategic Management and Competitive Advantage Concepts. Upper Saddle River, NJ: Pearson.

Black, J. A. and K. B. Boal (1994). 'Strategic resources: traits, configurations and paths to sustainable competitive advantage', Strategic Management Journal, 15, pp. 131148.

Blyler, M. and R. Coff (2003). 'Dynamic capabilities, social capital and rent appropriation: ties that split pies', Strategic Management Journal, 24, pp. 677-686.

Bowman, C. and V. Ambrosini (2000). 'Value creation versus value capture: towards a coherent definition of value in strategy', British Journal of Management, 11, pp. 115.

Castanias, R. P. and C. E. Helfat (1991). 'Managerial resources and rents', Journal of Management, 17, pp. 155-171.

Clark, K. B. (1985). 'A historical comparison of resource-based theory and five schools of thought within industrial organization economics: do we have a new theory of the firm?', Journal of Management, 17, pp. 121-154.

Coff, R. (1997). 'Human assets and management dilemmas: coping with hazards on the road to resource-based theory', Academy of Management Review, 22, pp. 374-402.

Coff, R. (1999). 'When competitive advantage doesn't lead to performance: the resource-based view and stakeholder bargaining power', Organization Science, 10, pp. $119-133$.

Collis, D. and C. Montgomery (1995). 'Competing on resources: strategy in the 1990s', Harvard Business Review, 73, pp. 118-128.

Davis, J. H., F. D. Schoorman and L. Donaldson (1997). 'Toward a stewardship theory of management', Academy of Management Review, 22, pp. 20-47. 
Dierickx, I. and K. Cool (1989). 'Asset stock accumulation and sustainability of competitive advantage', Management Science, 35, pp. 1504-1514.

Eisenhardt, K. M. (1989). 'Agency theory: an assessment and review', Academy of Management Review, 14, pp. 57-74.

Eisenhardt, K. M. and J. A. Martin (2000). 'Dynamic capabilities: what are they?', Strategic Management Journal, 21, pp. 1105-1121.

Feldman, M. S. and B. T. Pentland (2003). 'Reconceptualizing organizational routines as a source of flexibility and change', Administration Science Quarterly, 48, pp. 94-118.

Foss, K. and N. J. Foss (2005). 'Resources and transaction costs: how property rights economics furthers the resource-based view', Strategic Management Journal, 26, pp. 541-553.

Ghoshal, S. and C. A. Bartlett (1998). Managing Across Borders. London: Random House.

Grant, R. M. (1996). 'Toward a knowledge-based theory of the firm', Strategic Management Journal, 17, pp. 109-122.

Groysberg, B. and R. Abrahams (2006). 'Lift outs: how to acquire a high-functioning team', Harvard Business Review, 84, pp. 133-144.

Groysberg, B. and L. E. Lee (2008). 'The effects of colleague quality on top performance: the case of security analysts', Journal of Organizational Behavior, 29, pp. $1123-1144$.

Hales, C. (1999). 'Why do managers do what they do? Reconciling evidence and theory in accounts of managerial work', British Journal of Management, 10, pp. 335350.

Helfat, C. E., S. Finkelstein, W. Mitchell, M. Peteraf, H. Singh, D. Teece and S. Winter (2007). Dynamic Capabilities: Understanding Strategic Change in Organizations. London: Blackwell.

Henderson, R.M. and K.B. Clark (1990). 'Architectural innovation: the reconfiguration of existing product technologies and the failure of established firms', 
Administrative Science Quarterly, 35, pp. 9-30.

Hennart, J.-F. (1993). 'Explaining the swollen middle: why most transactions are a mix of "market" and "hierarchy"', Organization Science, 4, pp. 529-548.

Hunt, S. D. and R. M. Morgan (1995). 'The comparative advantage theory of competition', Journal of Marketing, 59, pp. 116.

Jenkins, M., K. Pasternak and R. West (2005). Performance at the Limit. Cambridge: Cambridge University Press.

Jensen, M. and W. H. Meckling (1976). 'Theory of the firm: managerial behavior, agency costs and ownership structure', Journal of Financial Economics, 3, pp. 305-360.

Johnson, G., L. Melin and R. Whittington (2003). 'Micro strategy and strategizing: towards an activity-based view', Journal of Management Studies, 40, pp. 1-22.

Johnson, G., K. Scholes and R. Whittington (2005). Exploring Corporate Strategy. London: Prentice Hall.

Kilpatrick, A. O. (1999). 'When in doubt, don't: alternatives to downsizing', Management, 2, pp. 209-219.

King, A. W. (2007). 'Disentangling interfirm and intrafirm causal ambiguity: a conceptual model of causal ambiguity and sustainable competitive advantage', Academy of Management Review, 32, pp. 156-178.

King, A. W. and C. P. Zeithaml (2001). 'Competencies and firm performance: examining the causal ambiguity paradox', Strategic Management Journal, 22, pp. 75-99.

Kogut, B. and U. Zander (1992). 'Knowledge of the firm, combinative capabilities, and the replication of technology', Organisation Science, 3, pp. 383-396.

Kor, Y. Y. and J. T. Mahoney (2004). 'Edith Penrose's (1959) contributions to the resource-based view of strategic management', Journal of Management Studies, 41, pp. $183-191$.

Kotowitz, Y. (1989). 'Moral hazard'. In J. Eatwell, M. Millgate and P. Newman (eds) The New Palgrave: Allocation, Information and Markets, pp. 207-213. New York: W. W. 
Norton.

Kulkarni, S. P. and N. Ramamoorthy (2005). 'Commitment, flexibility and the choice of employment contracts', Human Relations, 58, pp. 741-761.

Lado, A. A., N. G. Boyd, P. Wright and M. Kroll (2006). 'Paradox and theorizing within the resource-based view', Academy of Management Review, 31, pp. 115-131.

Lee, P. M. and H. M. O'Neill (2003). 'Ownership structures and R\&D investments of U.S., Japanese firms: agency and stewardship perspectives', Academy of Management Journal, 46, pp. 212-225.

Leiblein, M. J. (2003). 'The choice of organizational governance form and performance: predictions from transaction cost, resource-based, and real options theories', Journal of Management, 29, pp. 937-961.

Lepak, D. P., K. G. Smith and M. S. Taylor (2007). 'Value creation and value capture: a multilevel perspective', Academy of Management Review, 32, pp. 180194.

Lippman, S. A. and R. P. Rumelt (1982). 'Uncertain imitability: an analysis of interfirm differences in efficiency under competition', Bell Journal of Economics, 13, pp. 418438.

Lippman, S. A. and R. P. Rumelt (2003). 'The payments perspective; microfoundations of resource analysis', Strategic Management Journal, 24, pp. 903-927.

Lockett, A. and S. Thompson (2004). 'Edith Penrose's contribution to the resourcebased view: an alternative perspective', Journal of Management Studies, 41, pp. 193203.

Madhok, R. (2002). 'Reassessing the fundamentals and beyond: Ronald Coase, the transaction cost and resource-based theories of the firm and the institutional structure of production', Strategic Management Journal, 23, pp. 535-550.

Mael, F. and B. E. Ashford (1992). 'Alumni and their alma mater: a partial test of the reformulated model of organizational identification', Journal of Organizational Behavior, 13, pp. 103-123. 
Makadok, R. (2001). 'Toward a synthesis of the resource-based and dynamic capability views of rent creation', Strategic Management Journal, 22, pp. 387-401.

McEvily, S. K., S. Das and K. McCabe (2000). 'Avoiding competence substitution through knowledge sharing', Academy of Management Review, 25, pp. 294-312.

Mintzberg, H. and J. A. Waters (1985). 'Of strategies, deliberate and emergent', Strategic Management Journal, 6, pp. 257-272.

Morgan, R. M. and S. D. Hunt (1999). 'Relationship-bases competitive advantage; the role of relationship marketing in marketing strategy', Journal of Business Research, 46, pp. 281-290.

Mosakowski, E. (1997). 'Strategy making under causal ambiguity: conceptual issues and empirical evidence', Organization Science, 8, pp. 414-442.

Orlikowski, W. J. (2002). 'Knowing in practice: enabling a collective capability in distributed organizing', Organization Science, 13, pp. 249-273.

Pachedo-de-Almeida, G. and P. Zemsky (2007). 'The timing of resource development and sustainable competitive advantage', Management Science, 53, pp. 651-666.

Penrose, E. T. (1959). The Theory of the Growth of the Firm. Oxford: Blackwell.

Peteraf, M. A. (1993). 'The cornerstone of competitive advantage: a resourcebased view', Strategic Management Journal, 14, pp. 179-191.

Porter, M. E. (1996). 'What is strategy?', Harvard Business Review, 74, pp. 61-78.

Powell, T. C., D. Lovallo and C. Caringal (2006). 'Causal ambiguity, management perception, and firm performance', Academy of Management Review, 31, pp. 175-196.

Priem, R. L. and J. E. Butler (2001). 'Is the resource-based view a useful perspective for strategic management research?', Academy of Management Review, 26, pp. 2240.

Reed, R. and R. J. DeFillipi (1990). 'Causal ambiguity, barriers to imitation and sustainable competitive advantage', Academy of Management Review, 15, pp. 88-102.

Rivkin, J. (2001). 'Reproducing knowledge: replication without imitation at moderate 
complexity', Organization Science, 12, pp. 274-293.

Roberts, J., T. McNulty and P. Stiles (2005). 'Beyond agency conceptions of the work of the non-executive director: creating accountability in the boardroom', British Journal of Management, 16, pp. S5-S26.

Rumelt, R. (1984). 'Toward a strategic theory of the firm'. In R. Lamb (ed.), Competitive Strategic Management, pp. 556-570. Englewood Cliffs, NJ: Prentice Hall.

Rumelt, R. (1987). 'Theory, strategy and entrepreneurship'. In D. J. Teece (ed.), The Competitive Challenge, pp. 137-158. Cambridge, MA: Ballinger.

Simon, H. A. (1955). 'A behavioural model of rational choice', Quarterly Journal of Economics, 69, pp. 99-118.

Simonin, B. L. (1999). 'Ambiguity and the process of knowledge transfer in strategic alliances', Strategic Management Journal, 20, pp. 595-623.

Sundaramurthy, C. and M. Lewis (2003). 'Control and collaboration: paradoxes of governance', Academy of Management Review, 28, pp. 397-415.

Szulanski, G. (1996). 'Exploring internal stickiness: impediments to the transfer of best practice with the firm', Strategic Management Journal, 17, pp. 27-43.

Szulanski, G., R. Cappetta and R. J. Jensen (2004). 'When and how trustworthiness matters: knowledge transfer and the moderating effect of causal ambiguity', Organization Science, 15, pp. 600-613.

Teece, D. J., G. Pisano and A. Shuen (1997). 'Dynamic capabilities and strategic management', Strategic Management Journal, 18, pp. 509-533.

Thomke, S. and W. Kuemmerle (2002). 'Assets accumulation, interdependence and technological change: evidence from pharmaceutical drug discovery', Strategic Management Journal, 23, pp. 619-635.

Tosi, H. L., A. L. Brownlee, P. Silva and J. P. Katz (2003). 'An empirical exploration of decision-making under agency controls and stewardship structure', Journal of Management Studies, 40, pp. 2053-2071. 
Walsh, J. P. (1988). 'Selectivity and selective perception: an investigation of managers' belief structures and information processing', Academy of Management Journal, 31, pp. 873-896.

Whittington, R. (1996). 'Strategy as practice', Long Range Planning, 29, pp. 731-735.

Williamson, O. E. (1975). Markets and Hierarchies: Analysis and Antitrust Implications. New York: Free Press. Williamson, O. E. (1985). The Economic Institutions of Capitalism. New York: Free Press.

Winter, S. G. (1995). Four Rs of Profitability: Rents, Resources, Routines and Replication. Resource-Based and Evolutionary Theories of the Firm: Towards a Synthesis. Boston, MA: Kluwer Academic.

Zander, U. and B. Kogut (1995). 'Knowledge and the speed of transfer and imitation of organizational capabilities: an empirical test', Organization Science, 6, pp. 76-92.

Zollo, M. and S. G. Winter (2002). 'Deliberate learning and the evolution of dynamic capabilities', Organization Science, 13, pp. 339-351.

Véronique Ambrosini is a Professor of Strategic Management at Birmingham Business School. Her research is conducted essentially within the resource-based and dynamic capability view of the firm and the strategy-as-practice perspective. Véronique has published articles in academic journals such as Human Relations, Journal of Management Studies, British Journal of Management and Management Learning and practitioner oriented journals such as the European Management Journal.

Cliff Bowman is a Professor of Strategic Management at Cranfield School of Management. He was previously Director of Research at Ashridge. His current research interests include competitive strategy, dynamic capabilities, strategy processes and the development and leveraging of strategic assets. Cliff is the author of eight books and over 60 articles. 